\title{
Neurological complications following bariatric surgery
}

\author{
Complicações neurológicas da cirurgia bariátrica
}

Yara Dadalti Fragoso', Soniza Vieira Alves-Leon², Andréa de Carvalho Anacleto³, Joseph Bruno

Bidin Brooks ${ }^{1}$, Paulo Diniz da Gama4, Sidney Gomes 5 , Marcus Vinicius Magno Gonçalves ${ }^{6}$, Katia Lin? Josiane Lopes', Damacio Ramon Kaimen-Maciel', Fabiola Haschid Malfetano², Gladys Lentz Martins, Francisco Tomaz Menezes de Oliveira ${ }^{5}$, Leonardo Dornas Oliveira9 ${ }^{9}$ Rachel Schlindwein-Zanini ${ }^{10}$

\begin{abstract}
Objective: It was to report on Brazilian cases of neurological complications from bariatric surgery. The literature on the subject is scarce. Method: Cases attended by neurologists in eight different Brazilian cities were collected and described in the present study. Results: Twenty-six cases were collected in this study. Axonal polyneuropathy was the most frequent neurological complication, but cases of central demyelination, Wernicke syndrome, optical neuritis, radiculits, meralgia paresthetica and compressive neuropathies were also identified. Twenty-one patients (80\%) had partial or no recovery from the neurological signs and symptoms. Conclusion: Bariatric surgery, a procedure that is continuously increasing in popularity, is not free of potential neurological complications that should be clearly presented to the individual undergoing this type of surgery. Although a clear cause-effect relation cannot be established for the present cases, the cumulative literature on the subject makes it important to warn the patient of the potential risks of this procedure.
\end{abstract}

Key words: bariatric surgery, demyelination, neuropathy, Wenicke syndrome.

\section{RESUMO}

Objetivo: Foi relatar casos de pacientes brasileiros com complicações neurológicas da cirurgia bariátrica. A literatura no assunto é escassa. Método: Foram reunidos e descritos casos atendidos por neurologistas em oito cidades brasileiras diferentes. Resultados: Vinte e seis casos foram coletados neste estudo. A complicação neurológica mais frequente foi a polineuropatia axonal, mas também foram identificados casos de desmielinização central, síndrome de Wernicke, neurite óptica, radiculites, meralgia parestésica e neuropatias compressivas. Vinte e um pacientes (80\%) não tiveram recuperação ou tiveram apenas recuperação parcial dos sinais e sintomas neurológicos. Conclusão: A cirurgia bariátrica, procedimento cada vez mais popularizado, não está livre de potenciais complicações neurológicas as quais deveriam ser claramente expostas aos indivíduos que a ela se submetem. Embora não possa ser estabelecida uma clara relação causa-efeito entre essa cirurgia e os sinais e sintomas referidos nos casos aqui apresentados, a literatura consultada mostrou ser importante alertar o indivíduo acerca dos riscos potenciais envolvidos nesse procedimento.

Palavras-Chave: cirurgia bariátrica, desmielinização, neuropatia, síndrome de Wenicke.

\footnotetext{
${ }^{1}$ Neurology Service, Mental Health Department, Medical School of Universidade Metropolitana de Santos (UNIMES), Santos SP, Brazil;

${ }^{2}$ Neurology Service, Universidade Estadual do Rio de Janeiro (UERJ), Rio de Janeiro RJ, Brazil;

${ }^{3}$ Department of Neurology, Hospital Ana Costa, Santos SP, Brazil;

${ }^{4}$ Department of Neurology, Pontifícia Universidade Católica (PUC) de São Paulo, Campus Sorocaba, Sorocaba SP, Brazil;

${ }^{5}$ Department of Neurology, Hospital Beneficência Portuguesa and Hospital Paulistano, São Paulo SP, Brazil;

${ }^{6}$ Clínica Neurológica, Joinville SC, Brazil;

${ }^{7}$ Department of Neurology, Hospital Governador Celso Ramos, Florianópolis SC, Brazil;

${ }^{8}$ Neurology Service of the Internal Medicine Department, Universidade Estadual de Londrina (UEL), Londrina PR, Brazil;

${ }^{9}$ Neurology Service of the Internal Medicine Department, Faculty of Medicine, Universidade Federal de Minas Gerais (UFMG), Belo Horizonte MG, Brazil;

${ }^{10}$ Psychology Department, University Hospital, Universidade Federal de Santa Catarina (UFSC), Florianópolis SC, Brazil.

Correspondence: Yara Dadalti Fragoso; Department of Neurology, Medical School, Universidade Metropolitana de Santos (UNIMES); Rua da Constituição 374; 11015-470 Santos SP - Brasil; E-mail:yara@bsnet.com.br

Conflict of interest: There is no conflict of interest to declare.

Received 29 December 2011; Received in final form 25 May 2012; Accepted 04 June 2012
} 
The cost of obesity in the United States of America is estimated to be of the order of 100 billion dollars a year while circa 300,000 individuals die of obesity-related disorders annually in that country ${ }^{1}$. Clinical treatment for weight loss and weight control is difficult for many reasons, and perhaps the most important of them is the lifestyle and attitudes that led the person to gain so much weight. Changing one's lifestyle requires determination and motivation, and results will take a long time to be noticeable ${ }^{2}$. Bariatric surgery has appeared as an interesting option for those with severe/morbid obesity, frequently with other associated risk factors. As a rule, bariatric surgery can only be performed following strict recommendations, although it is a well-known fact that many overweight individuals who are willing to pay for the procedure, can have the surgery performed without following the strict guidelines.

Little, if anything, is discussed with the patient in relation to the potential neurological complications of this procedure ${ }^{3}$. The initial case series description of 23 patients with neurological complications was made by Abarbanel et al. ${ }^{4}$ and dates from 1987. It includes cases of polyneuropathy, burning feet syndrome, meralgia paresthetica, myotonic syndrome, myelopathy and Wernicke-Korsakoff encephalopathy. Since then, several other cases have been described and, 20 years later, Juhasz-Pocsine et al. ${ }^{5}$ described another case series with 26 patients presenting encephalopathy, optic neuropathy, myelopathy, polyradiculoneuropathy and polyneuropathy. In a comprehensive review on the subject, Berger ${ }^{6}$ listed the following possible complications of bariatric surgery: encephalopathy, behavioral abnormalities, seizures, cranial nerve palsies, ataxia, myelopathy, plexopathies, peripheral neuropathy, mononeuropathies, myopathy and myotonia.

The aim of the present paper was to highlight the potential neurological complications of bariatric surgery, a procedure that is continuously increasing in popularity. Classical and new forms of neurological manifestations in patients submitted to this surgery are presented and discussed in the light of the world literature on the subject.

\section{METHODS}

The present study was approved by the Ethics Committee of Universidade Metropolitana de Santos, Santos, SP. All other institutions participating in the study obtained separate authorizations for including cases in this report. Patients' confidentiality was assured by identification only by gender and age, without city of origin, patient's name or initials and/or photos.

A case of central nervous system demyelination following bariatric surgery was presented during a medical congress in Brazil in 2011. A group of neurologists and other health professionals in the area then decided to collect and report on their cases of neurological complications of bariatric surgery. Data collection occurred between March and April 2012.

The report was essentially descriptive and, therefore, no statistical analysis was performed.

\section{RESULTS}

Twenty-six cases (19 females and 7 males; average age $=42$ years; range 27-61 years) were collected from seven teaching neurological units in Brazil. A summary of these cases is shown in Table. The time elapsed between the surgical procedure and the onset of neurological signs and symptoms ranged from 10 days to 13 years. The most frequent neurological complication of bariatric surgery in this series of patients was axonal polyneuropathy ( $\mathrm{n}=10 ; 38.5 \%$ of cases), manifested between 45 days and 13 years after the surgical procedure, and usually associated with low levels of vitamin B12 (even in some patients who were taking vitamin B12 supplementation after surgery). One of the cases of peripheral neuropathy showed chronic denervation and signs of reinnervation of long evolution, and was confounded with amyotrophic lateral sclerosis.

Among the cases of peripheral neuropathies, other syndromes were identified. As a consequence of nerve compression occurring in cases of fast weight loss and the habit of crossing legs, peroneal mononeuropathy was identified in three cases. All of these cases showed partial or complete recovery with vitamin B12 supplementation and refraining from leg-crossing. There were two cases of meralgia paresthetica, and neither of them showed any improvement in the intensity of pain despite treatment. One case of acute brachial neuropathy and acute brachial radiculitis, known as the Parsonage-Turner syndrome, was also identified.

Another relatively frequent neurological observation was demyelination of the central nervous system (clinically manifested as multiple sclerosis relapse or multiple sclerosis-like attack), affecting five patients. Magnetic Resonance Image (MRI) in four of these cases fulfilled the diagnostic criteria for multiple sclerosis. One of them was already a patient with multiple sclerosis, and two new cases are now undergoing treatment with beta interferon. Furthermore, three cases presented rapidly progressing tetraparesia, with electrophysiological signs of motor neuron disease. Whether nutritional deficiencies might be responsible for these central nervous system manifestations remains to be clearly established.

Other isolated cases included two patients with optic neuritis, Wernicke syndrome, paraparesis with normal electrophysiological studies and magnetic resonance images of the brain and spinal cord. In three patients, an association of peripheral and central nervous system involvement was identified. Low levels of vitamins and other nutrients were not detectable in all patients because several of them were referred to the neurologist already using high doses of dietary 
Table. Summary of clinical data of patients submitted to bariatric surgery who present neurological symptons and signs that were attributed to be complications from the procedure.

\begin{tabular}{|c|c|c|c|}
\hline $\begin{array}{l}\text { Gender and } \\
\text { age (years) }\end{array}$ & $\begin{array}{c}\text { Time between } \\
\text { bariatric surgery } \\
\text { and neurological } \\
\text { symptoms }\end{array}$ & Neurological manifestations & Recovery \\
\hline$F-27$ & 10 days & Generalized weakness, incoordination, paresthesia & No \\
\hline$F-39$ & 1 month & Paresis and paresthesia identified at T12 level & Partial \\
\hline$M-59$ & 1 month & Lack of coordination in both arms, abasia, weakness, fatigue and paresthesia & Yes \\
\hline$F-20$ & 45 days & Weakness in both thighs, stocking paresthesia, abasia and astasia & Partial \\
\hline$F-38$ & 7 weeks & Confused, generalized pain and weakness, hyporeflexia, encephalopathy & Partial \\
\hline$F-31$ & 2 months & Tetraparesis with full recovery. Six months later new relapse of tetraparesis. & Partial \\
\hline$M-54$ & 3 months & Tetraparesis and hyperreflexia, generalized weakness, paresthesia and fasciculations & No \\
\hline$M-68$ & 4 months & Right brachial neuropathy & Lost to follow-up \\
\hline$F-28$ & 5 months & Weakness in the right leg, tendency to stumble & Partial \\
\hline$M-50$ & 6 months & Paresthesia (glove and stocking) & No \\
\hline$F-45$ & 6 months & Spastic paraparesis & Partial \\
\hline$F-35$ & 6 months & Generalized pain and weakness, hyporeflexia, hypoesthesia in stocking pattern & Partial \\
\hline$F-35$ & 9 months & Weakness in both legs, tendency to stumble, difficulties in walking & Complete \\
\hline$F-39$ & 10 months & Spastic paraparesis, sensitive ataxia, cognitive dysfunction (frontal lobe pattern) & Complete \\
\hline$F-37$ & 11 months & Generalized weakness and paresthesia & Partial \\
\hline$F-61$ & 1 year & Spastic paraparesis, asymmetric sensitive ataxia, optic neuritis and brain stem symptoms & Partial \\
\hline$M-38$ & 1 year & Relapsing episodes of optical neuritis, myelitis, ataxia, paraparesia & Partial \\
\hline$F-35$ & 16 months & Weakness and paresthesia in the right foot & Complete \\
\hline$F-43$ & 2 years & Paresthesia and sensitive ataxia & No \\
\hline$F-50$ & 4 years & Intense pain in lateral area of the right thigh & No \\
\hline$F-55$ & 4 years & Tetraparesia, dysarthria, dysphagia, hyperreflexia & No \\
\hline$F-53$ & 5 years & Intense pain in lateral area of the left thigh & No \\
\hline$M-40$ & 5 years & Optic neuritis & Complete \\
\hline$F-46$ & 6 years & Paraparesia, hyperreflexia & No \\
\hline$F-43$ & 10 years & Ataxia, spasticity, hyperreflexia, urinary incontinence & No \\
\hline$M-47$ & 13 years & Painful paresthesia in both legs, thermic distal hypoesthesia & No \\
\hline
\end{tabular}

supplements. In 12 cases, there were clear deficiencies of vitamins and nutrients (particularly copper), while in others the replacement may have masked the underlying condition of nutritional deficits.

The severity of the post-operative complication is clear since, as shown in Table, only $20 \%$ of all patients showed complete recovery from the neurological signs and symptoms.

\section{DISCUSSION}

The wide dissemination of bariatric surgery and the even more flexible criteria for patients' inclusion have led to some iatrogenic neurological complications, mainly related to nutritional deficits and dysfunctions. Fast and significant weight loss is usually associated with malabsorption of important nutrients, but the quick results seen by the patients may mask the potential unacceptable metabolic changes they could suffer. The idea that bariatric surgery is the alternative to balanced diets and drastic changes in lifestyle is attracting more and more obese patients to undergo such surgical procedures.
Chronic peripheral neuropathies are described as the most frequent neurological complication in patients who underwent bariatric surgery for weight loss?. These neuropathies can be presented as sensitive-motor polyneuropathy ${ }^{8}$, mononeuropathy ${ }^{9}$ or radiculoplexopathy ${ }^{10}$. This condition, although typical of patients operated many years earlier ${ }^{8}$, can also happen over the short term, as shown in several of the cases in the present series, in which these neuropathies were also very prevalent.

The rate of neurological complications following bariatric surgery has been estimated to range from 4.6 to $16 \%^{11}$, since some cases are subclinical. Most papers on the subject report polyneuropathy and mononeuropathies, Wernicke's encephalopathy, Guillain-Barré syndrome, behavioral abnormalities, seizures, cranial nerve palsies, ataxia, myelopathy, plexopathies, myopathy, myotonia and rhabdomyolysis ${ }^{3-21}$. The present study adds a list of Brazilian cases showing several forms of neurological complications from bariatric surgery. In addition to the classical abovementioned complications, five cases of central nervous system demyelination and three cases of motor neuron disease presentations represented potential 
complications of bariatric surgery. Although a strict causeeffect relationship is hard to obtain in these cases, these findings might be more than coincidental.

The authors are aware of the study limitations considering it was a retrospective and open series of cases. However, typical studies on the subjects follow the same methodology, and all authors were directly involved in caring for the patients reported here. Once again, it is worth mentioning that the time elapsed between the surgery and the neurological manifestations could suggest concomitant conditions. Nevertheless, the neurological disease presentation and evolution suggest a relationship between bariatric surgery, nutritional deficiencies and severe neurological complications.
In conclusion, the rate and severity of neurological complications following bariatric surgery demand that patients are well informed of these potential adverse events. Furthermore, the way in which bariatric surgery has become regarded as a trivial procedure can, at least partially, be blamed on media coverage of celebrities undergoing this procedure in order to lose weight quickly. The willingness of some surgeons to perform stomach reduction (Google gives nearly 5,000,000 hits for "bariatric surgery" and over 1,000,000 for "private clinics bariatric surgery") may add to the potential cases of serious (and often permanent) neurological complications of surgical procedures for weight loss.

\section{References}

1. Berger G. Obesity and managed care. Manag Care Interface 2007;20:36-37.

2. Knecht S, Ellger T, Levine JA. Obesity in neurobiology. Prog Neurobiol 2008;84:85-103.

3. Kumar N. Obesity surgery: a word of neurologic caution. Neurology 2007;68:36-38.

4. Abarbanel JM, Berginer VM, Osimani A, Solomon H, Charuzi I. Neurologic complications after gastric restriction surgery for morbid obesity. Neurology 1987;37:196-200.

5. Juhasz-Pocsine K, Rudnicki SA, Archer RL, Harik SI. Neurologic complications of gastric bypass surgery for morbid obesity. Neurology 2007;68:1843-1850.

6. Berger JR. The neurological complications of bariatric surgery. Arch Neurol 2004;61:1185-1189.

7. Thaisetthawatkul P, Collazo-Clavell ML, Sarr MG, Norell JE, Dyck PJ. A controlled study of peripheral neuropathy after bariatric surgery. Neurology 2004;63:1462-1470.

8. Menezes MS, Harada KO, Alvarez G. Painful peripheral polyneuropathy after bariatric surgery. Case reports. Rev Bras Anestesiol 2008;58:252-259.

9. Elias WJ, Pouratian N, Oskouian RJ, Schirmer B, Burns T. Peroneal neuropathy following successful bariatric surgery. Case report and review of the literature. J Neurosurg 2006;105:631-635.

10. Dyck PJ, Windebank AJ. Diabetic and nondiabetic lumbosacral radiculoplexus neuropathies: new insights into pathophysiology and treatment. Muscle Nerve 2002;25:477-491.
11. Feit H, Glasberg M, Ireton C, Rosenberg RN, Thal E. Peripheral neuropathy and starvation after gastric partitioning for morbid obesity. Ann Intern Med 1982;96:453-455.

12. Maryniak O. Severe peripheral neuropathy following gastric bypass surgery for morbid obesity. Can Med Assoc J 1984;131:119-120.

13. Harwood SC, Chodoroff G, Ellenberg MR. Gastric partitioning complicated by peripheral neuropathy with lumbosacral plexopathy. Arch Phys Med Rehabil 1987:68:310-312.

14. Chang CG, Adams-Huet B, Provost DA. Acute post-gastric reduction surgery (APGARS) neuropathy. Obes Surg 2004;14:182-189.

15. Koffman BM, Greenfield LJ,Ali II, Pirzada NA. Neurologic complications after surgery for obesity. Muscle Nerve 2006;33:166-176.

16. Cruz-Martinez A, Arpa J, Palau F. Peroneal neuropathy after weight loss. J Peripher Nerv Syst 2000;5:101-105.

17. Machado FC, Valério BC, Morgulis RNF, Nunes, KF, Mazzali-Verst S. Acute axonal polyneuropathy with predominant proximal involvement: an uncommon neurological complication of bariatric surgery. Arq Neuropsiquiatr 2006;64:609-612.

18. Singh S, Kumar A. Wernicke encephalopathy after obesity surgery: a systematic review. Neurology 2007;68:807-811.

19. de Oliveira LD, Diniz MT, de Fátima HS, et al. Rhabdomyolysis after bariatric surgery by Roux-en-Y gastric bypass: a prospective study. Obes Surg 2009;19:1102-1107.

20. Kumar N. Pearls: myelopathy. Semin Neurol 2010;30:38-43.

21. Ba F, Siddiqi ZA. Neurologic complications of bariatric surgery. Rev Neurol Dis 2010;7:119-124. 